\title{
Early Middle Palaeolithic occupations at Ventalaperra cave (Cantabrian Region, Northern Iberian Peninsula)
}

\author{
Joseba Rios-Garaizar
}

Prehistoric Technology Group, Centro Nacional de Investigación sobre la Evolución Humana (CENIEH), Paseo

Sierra de Atapuerca 3·09002, Burgos, Spain. Email: joseba.rios@cenieh.es

\begin{abstract}
:
The Middle Paleolithic assemblage from Ventalaperra level III, excavated in 1931 by Aranzadi and Barandiarán, was initially interpreted as being Aurignacian, and then as a Late Middle Paleolithic assemblage. Recent excavations at the site undertaken by Ruiz Idarraga and d'Errico have confirmed the Middle Paleolithic attribution, and have additionally produced data on subsistence strategies and environmental conditions. The results obtained from the technological analysis made on level III's assemblage suggest that its characteristics fit with an Early Middle Paleolithic attribution. The extensive use of local raw materials, the absence of ramified productions, and the use of centripetal (Levallois and Discoid) and SSDA flaking systems, link this assemblage with sites like Arlanpe and Lezetxiki VI which have been dated to the end of the Middle Pleistocene, or nearby sites such as Abrigo Rojo, still under study. This reveals a behavioral pattern for Early Middle Paleolithic populations in the eastern Cantabrian Region characterized by an extensive use of the landscape, high mobility, short occupations and a high dependence on local resources to assure subsistence and technological provisioning.
\end{abstract}

Keywords: Late Middle Pleistocene; Early Middle Paleolithic; lithic technology; mobility; Neanderthal; behavior

\section{Introduction}

Research on Middle Palaeolithic occupations in eastern Cantabria has expanded over the past several years thanks to new excavation projects and revision of classic sites. 25 years ago the Middle Palaeolithic presence in this region, with the exception of Lezetxiki's levels VI and VII, was restricted to the Upper Pleistocene (Baldeón 1990). The difficulties in applying numeric dating techniques and the insufficient background available for indirect chronological interpretation, spoke in favour of a conservative interpretation of the Middle Palaeolithic chronology in the region. The publication of new sequences with Early Middle Palaeolithic (EMP) occupations, such as that of Arlanpe cave (Rios-Garaizar et al. 2015), and the review of already-known sites such as Lezetxiki (Álvarez Alonso \& Arrizabalaga 2012), have shown that human presence in the region by the end of the Middle Pleistocene was greater than previously thought (Montes 2003). Nevertheless the majority of sites in this

Published by the School of History, Classics and Archaeology, University of Edinburgh ISSN: 2055-0472. URL: http://journals.ed.ac.uk/lithicstudies/

This work is licensed under a Creative Commons Attribution 2.5 UK: Scotland License. 
region are still related to the later phases of the Middle Palaeolithic, representing a key region to understand Neanderthal extinction (Higham et al. 2014; Rios-Garaizar 2012a).

The lithic assemblage of Ventalaperra cave's level III, excavated by J. M. Barandiarán and T. Aranzadi in 1931, was initially attributed to the Aurignacian (Barandiarán 1958) and later to the Late Middle Palaeolithic (LMP) (Baldeón 1987; 1990), although no clear evidence sustained these attributions. More recent studies tend to link level III occupations with the Mousterian (Arrizabalaga 1995; 2005). A preliminary study of this assemblage aimed to characterize the eastern Cantabrian LMP in the region, but some elements revealed important differences with these techno-complexes. This study, alongside data published from recent excavations carried out between 2001 and 2004 by Ruiz-Idarraga and d'Errico (2002; 2003; 2004; 2005), will offer elements for discussion on the chronology and cultural attribution of these occupations, and will aim to explain the technological organization strategies implemented by Neanderthal groups occupying the site.

\section{Site description}

The cave of Ventalaperra (also known as Venta de la Perra or Venta Laperra) is located in a limestone gorge crossed by the Carranza River, a tributary of the Ason River. The landscape surrounding the cave is characterized by many biotopes such as the coastal plains, flat and open valleys, and mountainous areas, very abundant around the cave. From the site it was also easy to access the Ason Valley, which was a major communication axis during the whole of the Palaeolithic, communicating the coastal plains with the Meseta through the Los Tornos mountain pass (918 $\mathrm{m}$ a.s.l.). The Carranza Valley also allowed easy communication with the eastern valleys of Agüera and Barbadun through the La Escrita mountain pass (430 $\mathrm{m}$ a.s.l.) (Figure 1).

Several sites with Middle Palaeolithic industries are found within the Ason Valley and along this river's tributaries. In the western part of the Valley, at the cave of Cofresnedo, a single level linked to Mousterian occupations has been identified (Ruiz Cobo \& Smith 2003). Further east, El Mirón cave has a single Mousterian level (lv. 130) in the deep sondage excavated in the Vestibule Rear zone, which has been dated to 41,280 \pm 1120 uncal. BP (GX27112). This level, however, yielded very few materials, among them two flake denticulates (Straus \& González Morales 2003). Close to El Mirón one finds the Abrigo Rojo or Abrigo de los Abandejos rock shelter, where a rich lithic and faunal assemblages were recovered on the surface and in a small test trench opened up in 2006 by M.R. González Morales (personal communication with González Morales in 2015). The characteristics of the lithic assemblage recovered at this site, studied by us in 2010, suggest an Early Middle Palaeolithic (EMP) attribution. In the same valley, the Arco A, B and C caves have yielded lithic assemblages attributed to the Middle Palaeolithic. At Arco A the remains of a Middle Palaeolithic layer were discovered during the works of enclosure of the cave (Muñoz Fernández 2005); at Arco B a similar level was also identified. At both sites and in Arco C many lithic materials have been recovered from the surface of the cave, among them several cleavers (González Sáinz \& San Miguel Llamosas 2001). Additionally, at Cueva Chiquita some Middle Palaeolithic materials were also recovered on the surface (Muñoz Fernández 2005), but, as is the case for the Arco A-C caves, no clear attribution to the LMP is possible. At Polvorín cave the presence of a possible Middle Palaeolithic occupation and a possible Neanderthal deciduous premolar has been mentioned in recent reports (Ruiz Idarraga \& d'Errico 2007).

The Ventalaperra cave mouth $(20 \times 10 \mathrm{~m})$ opens up on a limestone cliff at $180 \mathrm{~m}$ a.s.l. (60 $\mathrm{m}$ above the bottom of the valley), facing SW (UTM 30, ETRS89 x:468310 y:4789031 $\mathrm{z}: 168)$. The entrance chamber, where the archaeological excavations took place and rock art was found, is quite small (15 x $10 \mathrm{~m}$ maximum). Following this chamber the cave extends for 
a further hundred meters, although no archaeological evidence has been found in the internal galleries.

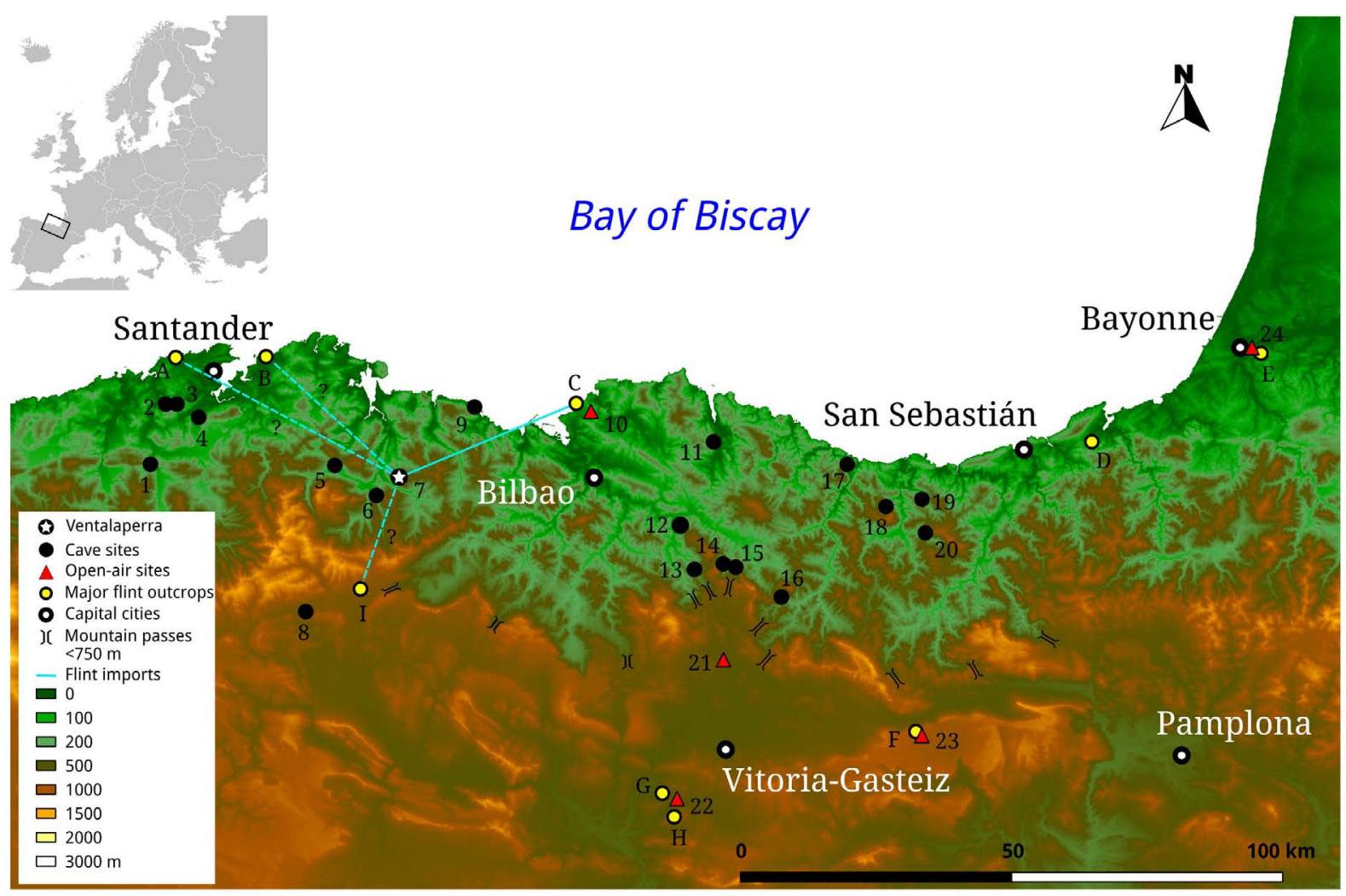

Figure 1. Map showing the location of Ventalaperra and the most important MP sites and flint sources in the region. 1: El Castillo; 2: Covalejos; 3: EL Pendo; 4: Cueva Morín; 5: Cofresnedo; 6: Abrigo Rojo; 7 : Ventalaperra; 8: Prado Vargas; 9: El Cuco; 10: Aranbaltza, Kurtzia; 11: Atxagakoa; 12: Arlanpe; 13: Axlor; 14: Askondo; 15: Asuntze; 16: Lezetxiki; 17: Zerratu; 18: Astigarraga; 19: Arnaileta; 20: Amalda; 21: Urrunaga; 22: Murba; 23: Mugarduia Norte; 24: Avenue des Prises. Flint sources: A: Monte Picota; B: Langre; C: Kurtzia Flysch; D: Gaintxurisketa Flysch; E: Bidache Flysch; F: Urbasa; G: Treviño; H: Loza; I: Ojo Guareña.

The rock art was discovered in 1904 by L. Sierra, who also collected some surface materials, including Upper Palaeolithic remains and ceramics (Alcalde del Río et al. 1912: 18). In 1931 J.M. Barandiarán and T. Aranzadi excavated the cave. The excavation was carried out on an approximately $6 \mathrm{~m}^{2}$ surface, which was originally divided into four sectors (A-D) approximately $1 \times 1.5 \mathrm{~m}$ each (Figure 2).

The depth of the materials were recorded and four levels identified: a superficial level (Level I) with recent prehistoric material, including lithics, fauna and ceramics; Level II (between 20-35 cm below the surface), contained bone and lithics, including a backed point fragment; Level III (between 35-45 cm below the surface), with lithics and faunal remains; and finally another level situated around $-70 \mathrm{~cm}$ with flint and 'ophite' pieces of a Mousterian aspect (Barandiarán 1958). In a later publication (Barandiarán 1978) this stratigraphy was reinterpreted, and additionally the initial sectors were converted into a normal excavation grid (Figure 2). The materials were grouped into two levels, an initial level with loose earth (between 0 and $22 \mathrm{~cm}$ below the surface), which included faunal remains, lithics, a polished stone axe and ceramics, attributed to the end of Neolithic (Barandiarán 1978: 129); and a second level composed of reddish and hardened sediments (between 35-70 cm below the surface) with faunal and lithic remains, attributed to the Aurignacian (Barandiarán 1978: 129). The review carried out by A. Baldeón (1990) identified three different levels (I - Superficial (possibly), II and III) and the lower level was interpreted as being Typical 


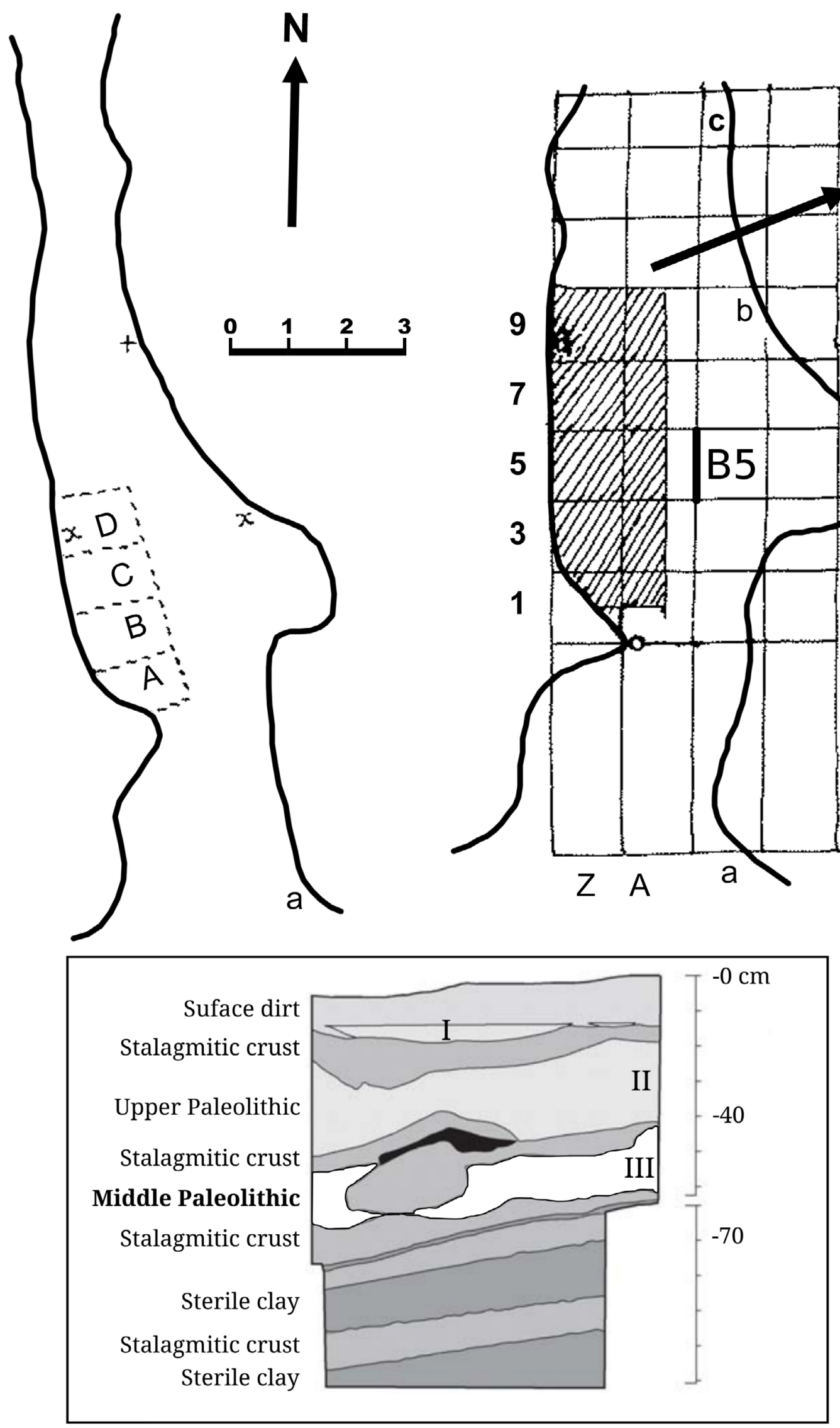

Figure 2. Plan of the 1931 excavation. Left: the original published in 1958 (Barandiarán 1958) including the excavated sectors and the position of the decorated panels. Right: the variation published in 1978 (Barandiarán 1978). Below: Synthetic stratigraphy obtained in the recent excavations (modified from Murelaga et al. 2007). 
Mousterian containing some blade types closer to the Aurignacian. For this reason, the level was tentatively dated to the Würm III (Baldeón 1990). Recent excavations at Ventalaperra undertaken by R. Ruiz-Idarraga and F. d'Errico, between 2001 and 2004, were conducted beside Barandiarán and Aranzadi's opened section. The stratigraphy defined by Barandiarán was roughly confirmed by the new data, and more layers below level III (level 4 in the new excavations), all of them sterile, were excavated. The descriptions offered by R. Ruiz-Idarraga and F. d'Errico (2002; 2003; 2004; 2005) together with the stratigraphy represented in a recent paper by Murelaga et al. (2007) reveal a superficial level (1), followed by a dark brown, almost sterile level (level 2). Under level 2 a thick and continuous flowstone was excavated (level 3), and below it a reddish and hardened sediment containing lithics and faunal remains was uncovered (level 4). The archaeological assemblage from level 4 is described as a rich archaeological level with abundant faunal remains and a rich lithic assemblage comprising big flakes, many of them made on microquartzite, which allowed this level to be attributed to the Mousterian. Up to now no date is available for level 4, but the flowstone between levels 2 (Upper Palaeolithic) and 4 (Mousterian) was sampled for U-Th and TL dating (Ruiz Idarraga \& d'Errico 2002).

A study of the micromammal assemblage reveals temperate and humid environmental conditions during the formation of level 4, which would have been colder than during level 2's given the appearance of alpine marmot (Marmota marmota) and tundra vole (Microtus oeconomus) in the older level (Murelaga et al. 2007).

The faunal assemblage is clearly dominated by rocky-environment ungulates such as Spanish ibex (Capra pyrenaica), followed by ungulates typically found on plains or in forests such as red deer (Cervus elaphus) and roe deer (Capreolus capreolus). Among the few carnivores recovered from level 4 the presence of brown bear (Ursus arctos) and wolf (Canis lupus) is noteworthy (Castaños 2005). The faunal assemblage represents a diet based mainly on animals present within the cave's immediate environment.

\section{Material and methods}

The lithic assemblage from the first excavations at Ventalaperra comprises 202 artefacts. The excavation of Ventalaperra site was made at the beginning of the $20^{\text {th }}$ century, at this time the excavation procedures were very different from current standards, and very probably the collection could bear some biases. Otherwise, in other excavations made by Barandiaran (i.e. Axlor) we have observed a certain underrepresentation of non-flint materials, which appear in bigger quantities in modern excavations (Rios-Garaizar 2012a: 324-326). This could be also the case of Ventalaperra and the relevance of non-flint raw materials may be underestimated.

The material has been recently classed according to its square of provenance and depth, but we must keep in mind that during the excavation no regular grids were used. This has led to some inconsistencies between the labels and the actual grid. For example, some pieces have been labelled as coming from square $17 \mathrm{Y}$, but such a square does not exist. Also, in the drawings made by Barandiarán for the 1978 publication, some pieces are labelled as 17A or 13Z, but these squares were not excavated. Finally, some of the pieces drawn by Barandiarán and labelled as $5 \mathrm{Z}$ in the 1978 publication are actually physically labelled as 15Z. It is likely that during the square-assignation process from the original sectors some mistakes were made; it is also likely that the only kind of reliable information is that of the depth below the original surface. Taking this into account, four major assemblages can be identified: pieces found at $c$. $-22 \mathrm{~cm}$ (Level I, N=50); pieces found at $c$. $-35 \mathrm{~cm}$ (Level II, $\mathrm{N}=40$ ); pieces found at $c .-50 \mathrm{~cm}$ (Level III, $\mathrm{N}=88$ ); and pieces found at $c$. $-70 \mathrm{~cm}$ (Level III, $\mathrm{N}=20$ ). The present study will focus only on the materials from level III (108 remains). 
The raw material has been classified according to the major raw material categories, namely flint, mudstone, quartz and quartzite. Flint varieties have been classified following A. Tarriño (2006) and J. Rissetto's (2008) flint-type definitions. For some flint types, such as La Cadena flint-type, personal observations have been used (Rios-Garaizar 2004: 85). Mudstone has been defined using information derived from previous observations at other sites such as Arlanpe (Rios-Garaizar 2013) and those made by others (Rissetto 2005). The same is true for quartz and quartzite. Raw materials have been grouped into ultra-local $(<1 \mathrm{~km})$, local $(<10$ $\mathrm{km})$ and non-local (>10 km) varieties. Raw material relevance has been analysed taking into account the total number of artefacts and their weight.

For the technological analysis different variables have been considered. Blanks were classified following a list based on J. M. Geneste's work (Geneste 1988) adapted to the study of eastern Cantabrian Region Middle and Upper Palaeolithic sites (see, for example, RiosGaraizar 2012a: 23-36; Rios-Garaizar et al. 2011). Different morphometric data were recorded for each piece (dimensions, knapping angles, previous scar direction, cortical surfaces, etc.), and for every retouched edge (dimensions, delineation, angle, type of retouch, etc.). No use-wear analysis was carried out, although morpho-functional inferences have been recorded (position of the potential edges, etc.).

\section{Results}

Level III has yielded 108 lithic artefacts, most of them flakes, outrepassé flakes and cortical flakes. Other elements such as cores and resharpening flakes are less abundant (Table 1). Formal retouched tools are quite abundant (19.4\%), being side-scrapers the most represented tool type (Table 2)

Table 1. Technological composition of Ventalaperra's level III (depth between -45 and -70 cm), Barandiarán and Aranzadi's collection.

\begin{tabular}{|c|c|c|c|c|c|c|c|}
\hline & \multirow[b]{2}{*}{ Limestone } & \multirow[b]{2}{*}{ Quartzite } & \multirow[b]{2}{*}{ Quartz } & \multirow[b]{2}{*}{ Mudstone } & \multicolumn{3}{|c|}{ Urgonian } \\
\hline & & & & & Flint & Flint & Total \\
\hline Core & & & 1 & & & 3 & 4 \\
\hline Flake Core & & & & 2 & & 1 & 3 \\
\hline Cortical Flake & & 1 & 1 & 4 & 3 & 7 & 16 \\
\hline Outrepassé flake & & & 1 & 3 & 10 & 7 & 21 \\
\hline Overshot flake & & 1 & & & & 1 & 2 \\
\hline Flake & & 6 & 1 & 3 & 13 & 7 & 30 \\
\hline Blade & & & & & 1 & & 1 \\
\hline Resharpening flake & & & & & 5 & 3 & 8 \\
\hline Bifacial resharpening flake & & & & 1 & & & 1 \\
\hline Splint & & & & & & 3 & 3 \\
\hline Fragments and debris & & & & & & & \\
\hline$<10 \mathrm{~mm}$ & & 4 & & 1 & 3 & 9 & 17 \\
\hline Used or flaked pebble & 1 & & & 1 & & & 2 \\
\hline Total & 1 & 12 & 4 & 15 & 35 & 41 & 108 \\
\hline Weight (g) & 121.4 & 93.5 & 60.3 & 511.1 & 156 & 308.5 & 1250.8 \\
\hline
\end{tabular}


Table 2. Typological composition of Ventalaperra's level III (depth between -45 and -70 cm), Barandiarán and Aranzadi's collection.

\begin{tabular}{lccccc}
\hline & Quartzite & Quartz & Urgonian Flint & Flint & Total \\
\hline Side-scraper & & & 3 & 9 & 14 \\
$\begin{array}{l}\text { Denticulated side-scraper } \\
\text { Denticulate }\end{array}$ & 1 & 1 & 1 & & 2 \\
Retouched flake & 2 & & & 1 & 2 \\
\hline Total & 3 & 2 & 4 & 12 & 3 \\
\% retouched & 25 & 50 & 9.8 & 34.3 & 19.4 \\
\hline
\end{tabular}

Raw material composition in level III (-45 to $-70 \mathrm{~cm}$ depths) is characterized by a great variability, with local raw materials $(<10 \mathrm{~km})$ representing the most abundant kind (Figure 3 and Figure 4).

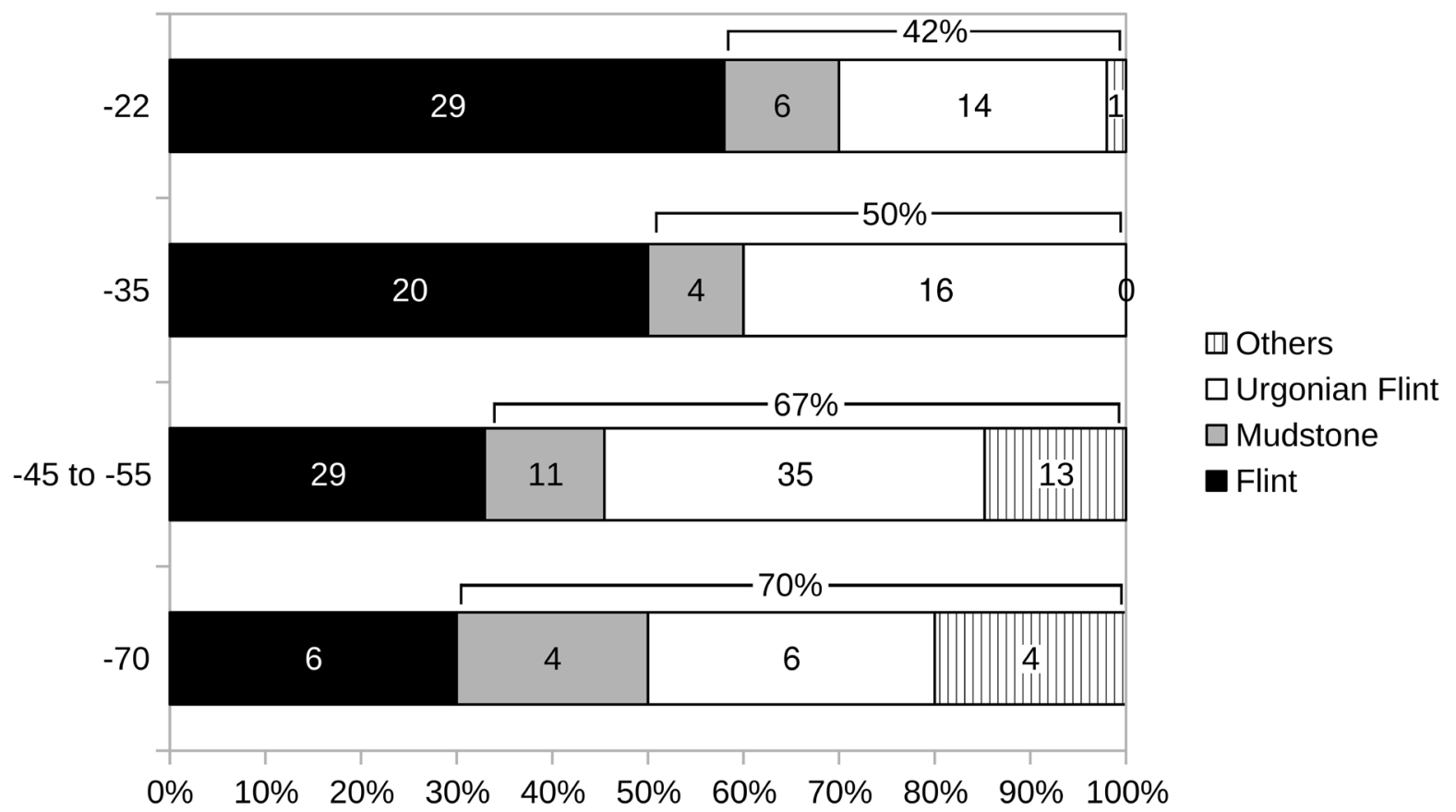

Figure 3. Raw material composition at different level depths, $-22 \mathrm{~cm}$ (level I); $-35 \mathrm{~cm}$ (level II); $-45 \mathrm{~cm}$ to -70 cm (level III).

Among the local raw materials, the Lower Cretaceous 'Urgonian' flint is the most abundant. This flint is nowadays found in the limestones of La Cadena (Carranza), where the cave itself is located (Rios-Garaizar 2004: 85), so it can be considered as ultra-local. This flint is of medium-quality because it presents numerous natural cracks and impurities (Figure $5 \mathrm{E}$ F), which makes knapping quite unpredictable; nevertheless with this kind of flint it is always possible to obtain suitable fragments with useful edges. The mudstone is a local raw material. This fine-grained and partially-silicified material is good for knapping and produces mediumquality edges. It was obtained as pebbles from secondary deposits in river banks. Lower Cretaceous geological strata bearing mudstone nodules have been cut by the Carranza River 1 km downstream, so this material was probably quite easily accessible. Good- and mediumquality quartzite is present in low quantities in the nearby riverbanks. Also, exploitable quartz beds are present around the site (Rissetto 2005).

Beside these local and ultra-local raw materials, every level produced a variable amount of non-local raw materials, with Upper Cretaceous flint representing the most abundant type. 
Two main varieties are present. Flysch flint is nowadays present on the western coast of the Biscay region, $37 \mathrm{~km}$ away from Ventalaperra in a NE direction, but it is likely that other closer (20-30 km) outcrops were present between Santoña and Plentzia. This is a high-quality flint characterized by the presence of abundant bioclasts, especially sponge spiculae (Figure 5 A-B). The presence of neo-cortical surfaces with marine abrasion indicates that this flint was picked up from secondary deposits. The other variety is a blue-white coloured translucent flint, with irregular colour zones and abraded neo-cortical surfaces. This flint is characterized by the presence of idiomorphic dolomite rhombs and chalcedony geodes (Figure 5 C-D). The most probable source for this flint variety is the Eocene external marine platform outcrop from Virgen del Mar, near Santander (Tarriño et al. 2015), $50 \mathrm{~km}$ away NW. Nevertheless similar flint has been described in Langre (35 km NW) and near Ojo Guareña (25 km S) (Rissetto 2008).

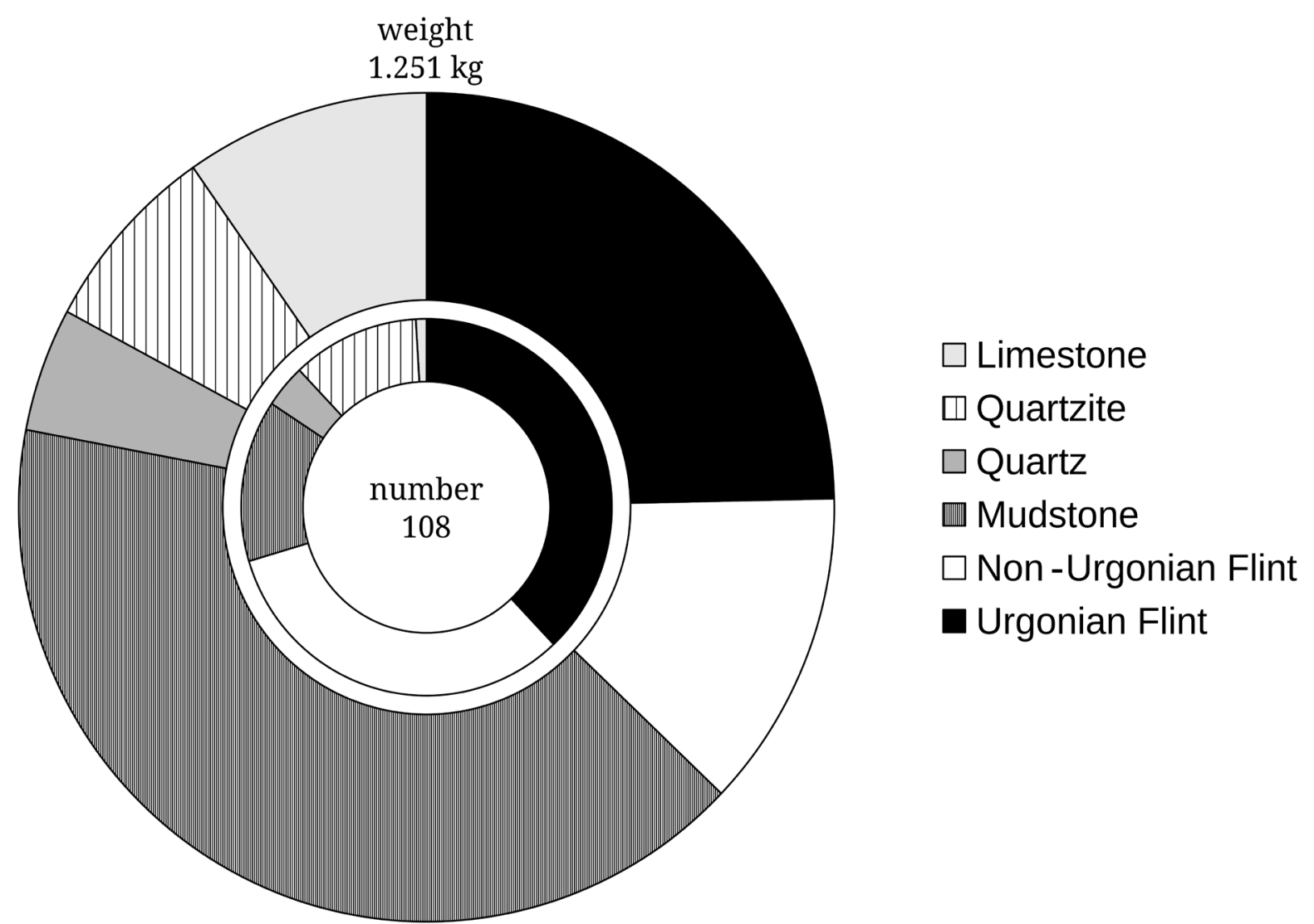

Figure 4. Relationship between raw material compositions taking into account number of artefacts and weight.

When considering the weight of the transported raw material, the importance of nonUrgonian flint decreases considerably, whereas that of mudstone is far more important (Figure 4). This is also due to the bigger size of the artefacts made on mudstone, including two large cores.

There are also differences in the management of the different raw materials. Fragments of raw Urgonian flint were picked up from the limestone. The morphology of these fragments was roughly parallelepiped, with many natural cracks. This makes it almost impossible to use a production strategy other than an opportunistic one. These natural fragments are shattered and the resultant fragments are sorted, some of them regular enough to define regular edges by retouch or to use as core on flakes to produce small flakes. One small core found at a -70 cm depth had produced a single flake, the same as another core found at -55 or $-45 \mathrm{~cm}$ depth. Another core is a plaquette from which quadrangular flakes have been obtained through 
bipolar percussion. Finally, there is a fragmented core from -55 or $-45 \mathrm{~cm}$ depth with a cortical surface preserved on one side, a faceted platform and a flat flaking surface which has been centripetally exploited (Figure 6.1). At this same depth, a single pseudo-Levallois point made on good-quality Urgonian flint was also found (Figure 6.2). Only four retouched tools made on this raw material come from this level. One is a denticulated side-scraper (Figure 6.4), two others are side-scraper fragments, and the final one is a Quina-like side-scraper made on the ventral surface (Figure 6.3). Finally, the presence of resharpening flakes also accounts for the occasional transformation of suitable fragments and flakes into side-scrapers. The abundance of trimming flakes, fragments, opportunistic cores and by-products suggests that the Urgonian flint reduction sequence took place entirely at the cave.
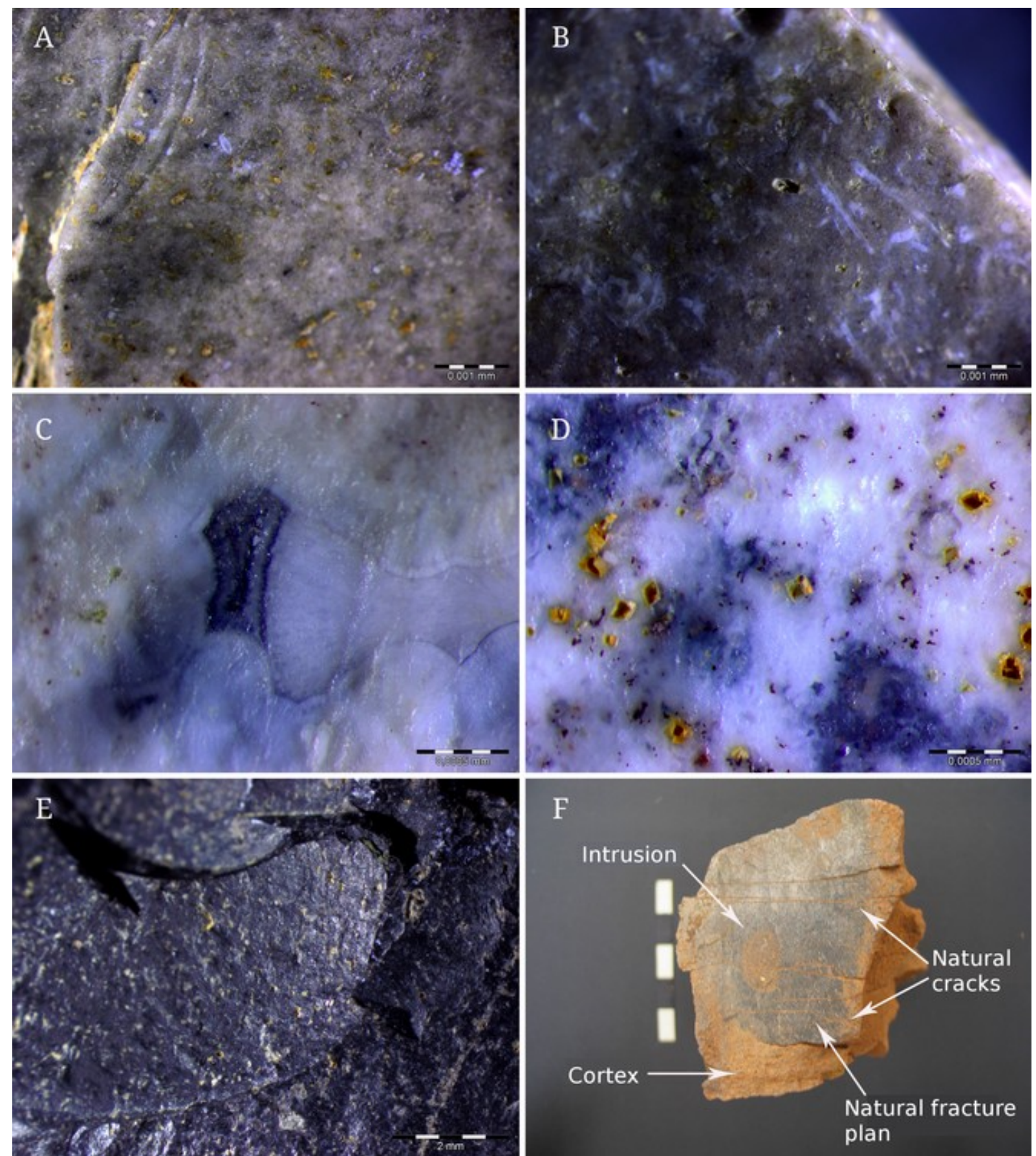

Figure 5. Microscopic and macroscopic textures of different flint types from Ventalaperra's level III: A-B: Flysch flint; C-D: Translucent flint; E-F: Urgonian flint. 

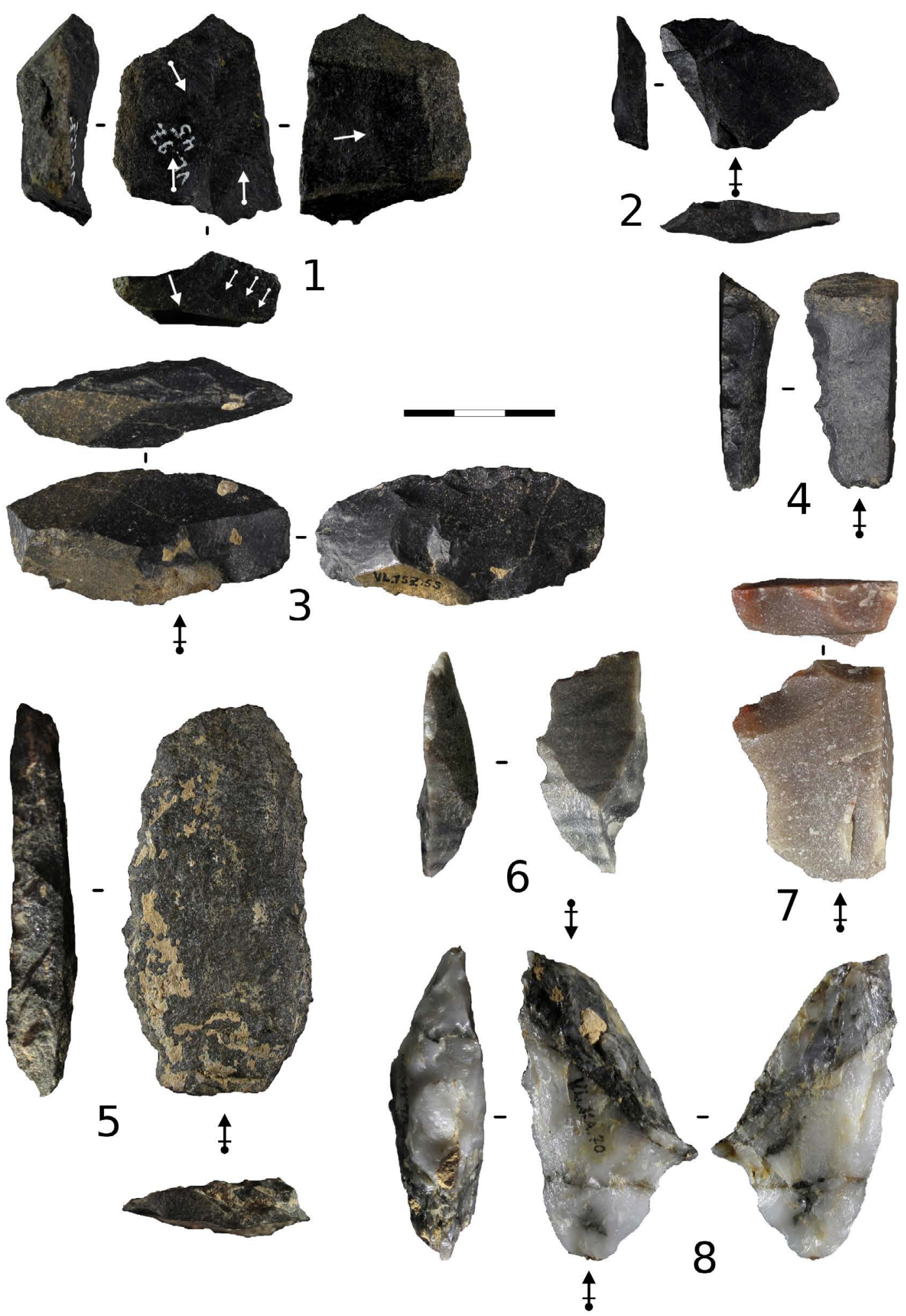

Figure 6. 1-4 Urgonian flint artefacts: 1: centripetal core; 2: Pseudo-Levallois point; 3: Transversal side-scraper made on ventral surface; 4: Denticulate side-scraper. 5-7: Quartzite artefacts: 5: Denticulate side-scrapers; 6-7: Denticulate. 8: Quartz flake obtained by bipolar percussion transformed into a denticulate side-scraper. The scale bar is $3 \mathrm{~cm}$.

The mudstone assemblage is characterized by the presence of big cortical flakes, flatconvex centripetal cores and the products obtained from these cores. The two cores present two different exploitation surfaces. One is rather flat and shows a recurrent centripetal 
exploitation (Figure 7.1). The other is convex, almost pyramidal in one case, having been used in flake production and platform preparation (Figure 7.2). The direction of the extractions on the flat surface is centripetal, oriented towards the centre of the core, and the obtained flakes are quadrangular (final flakes: 39x36 mm). In both cases, the angle between both surfaces is relatively acute $\left(60-70^{\circ}\right)$. The mudstone flakes can be divided into two groups. One is composed of big, partially-cortical flakes, with flat platforms, asymmetric sections, acute edges showing macro-wear traces and some retouch on the distal part used to facilitate handling (Figure 8.1-3). The other group is composed of non-cortical flakes, with prepared platforms (dihedral and asymmetrically dihedral platforms) and centripetal negatives, which correspond to the production obtained from the aforementioned cores (Figure 8.5-7). A single, wide flake, with a very high detachment angle and angular platform seems to be a by-product of bifacial shaping (Figure 8.4). Unlike the Urgonian flint reduction sequence, the composition of the mudstone assemblage suggests that production took place away from the cave, and that the functional raw products and already-exploitable cores were transported back to the site from a nearby locality.

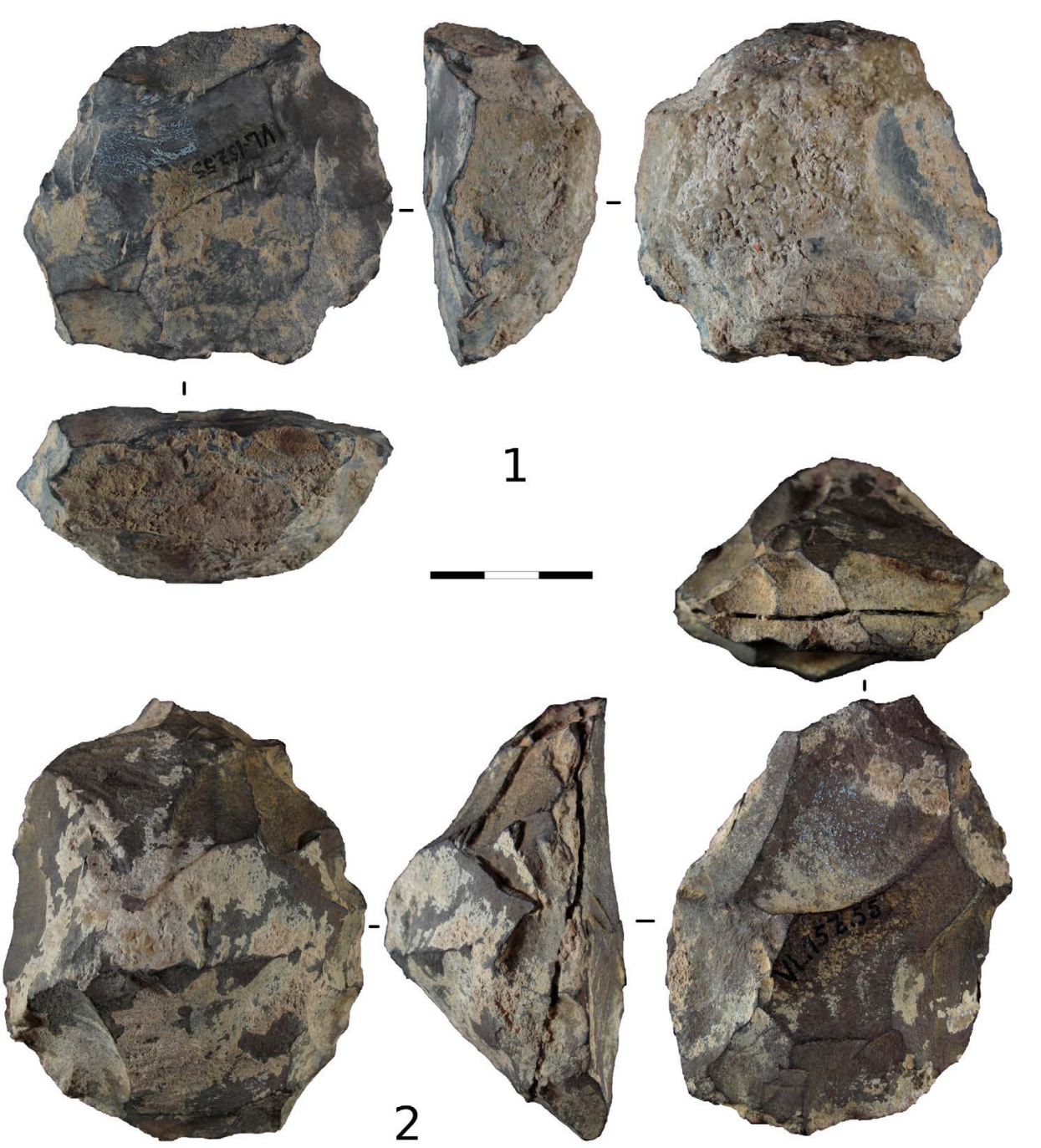

Figure 7. Mudstone flat-convex centripetal cores. Ventalaperra level III.

The quartzite assemblage is mainly composed of two different varieties, one fine-grained and the other more coarse-grained. The only cortical flake found presents a neocortical eroded surface (Figure 6.5). The majority of the blanks made on this raw material are flakes and fragments of flakes. Two of them have prepared platforms (faceted and dihedral) and the 
organization of the previous extractions is centripetal. Two pieces have been transformed into denticulates (Figure 6.6-7), and another into a denticulate side-scraper (Figure 6.5).
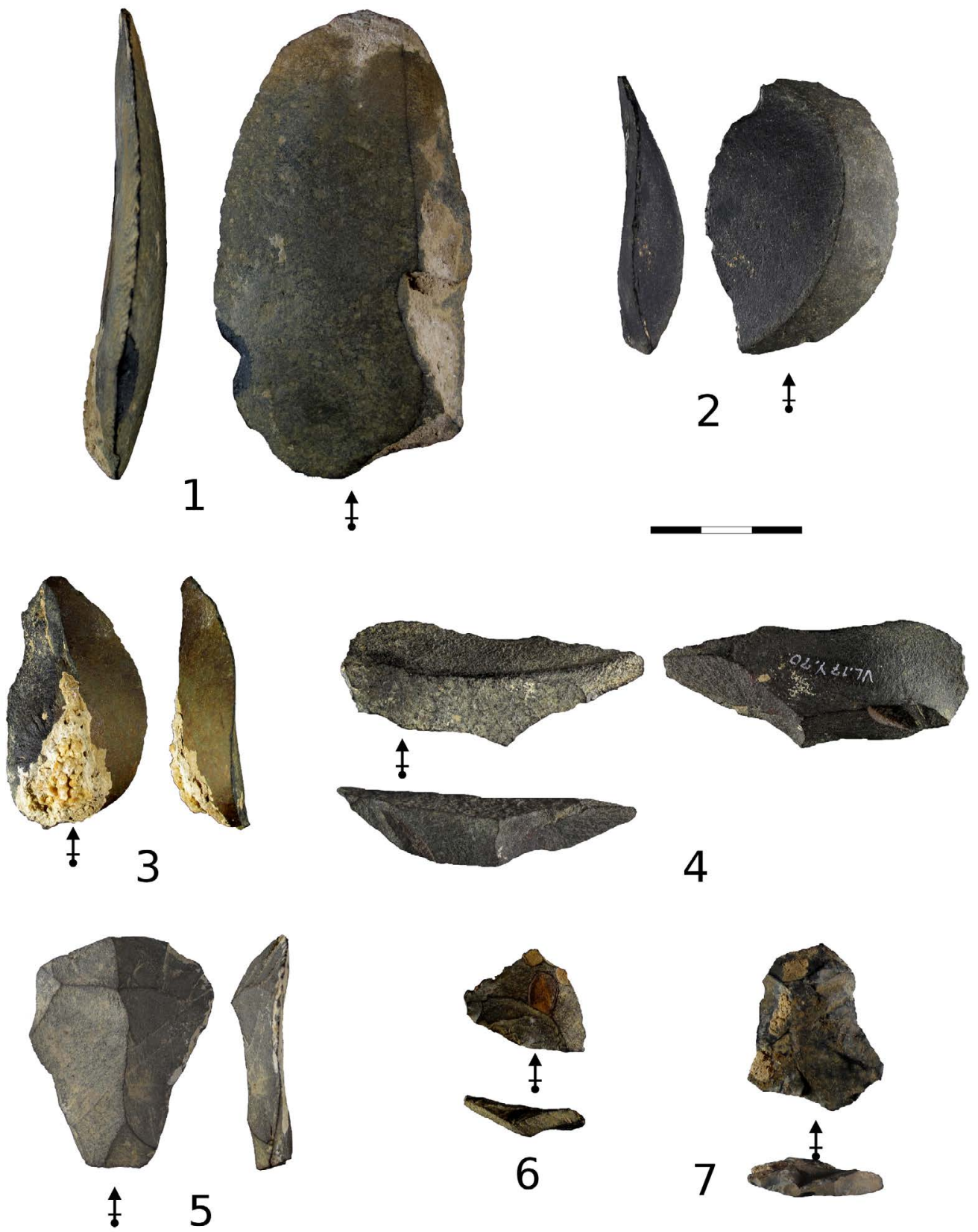

Figure 8. Mudstone products. 1-3: partially cortical flakes; 4: by-product of bifacial shaping; 5-7: non-cortical flakes with centripetal negatives and dihedral platforms (6-7). Ventalaperra level III.

Quartz was scarcely used, in the $-70 \mathrm{~cm}$ depth assemblage there is a small bipolar percussion flake core and a big cortical flake, extracted by bipolar percussion, which also presents some thick retouches (Figure 6.8). In the -45 to $-55 \mathrm{~cm}$ depth assemblage there are two more flakes, with one cortical flake transformed into a denticulate side-scraper.

The non-Urgonian flint (Flysch and Translucent flint) assemblage has a different composition. The most represented category is that of simple flakes, follow by outrepassé flakes and resharpening flakes. 25\% of these flakes are retouched. Most of the outrepassé flakes overtake a cortical flank (Figure 9.1-2, 9.7, 9.9), showing that most of the cores were not entirely prepared, which is, on the other hand, a common characteristic in most Levallois 
cores recovered in flint workshops around Kurtzia (see, for example, Rios-Garaizar et al. 2010). Regular flakes and outrepassé flakes usually have flat platforms, but some of them display typical faceted platforms (Figure 9.3, 9.5, 9.6). Previous negatives show that knapping sequences followed a centripetal system. The proportion of retouched tools, mostly sidescrapers, some of them quite thick (Figure 9.1-4), and the presence of resharpening flakes, one of them retouched (Figure 9.10), account for a specific management of non-Urgonian flint tools based on the transport of already-made tools as part of a personal toolkit. Other retouched tools are less invested, showing partially retouched edges (Figure 9.5, 9.9), simple denticulate edges (Figure 9.6), or bifacially-denticulated edges (Figure 9.7, 9.10).
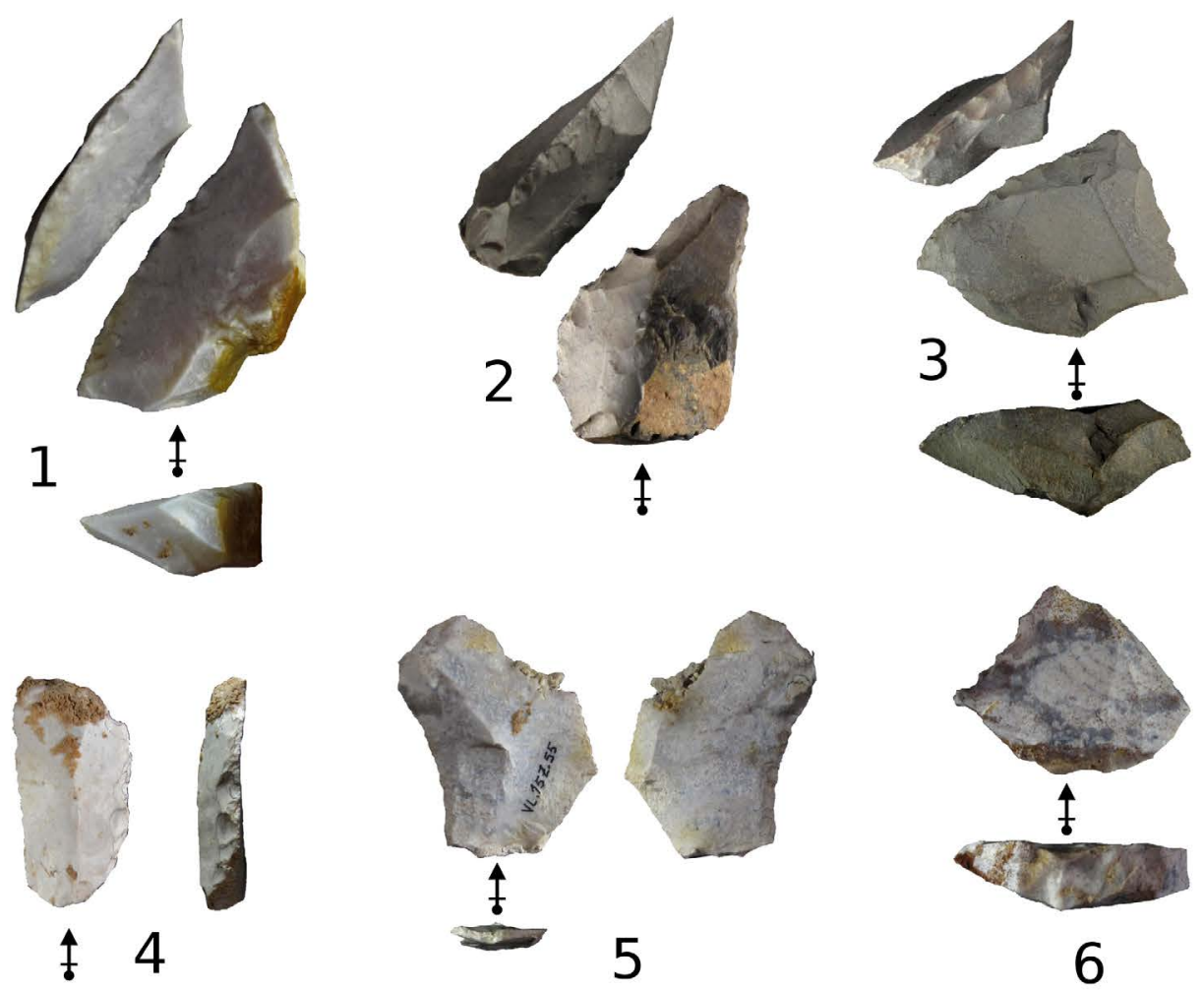

6
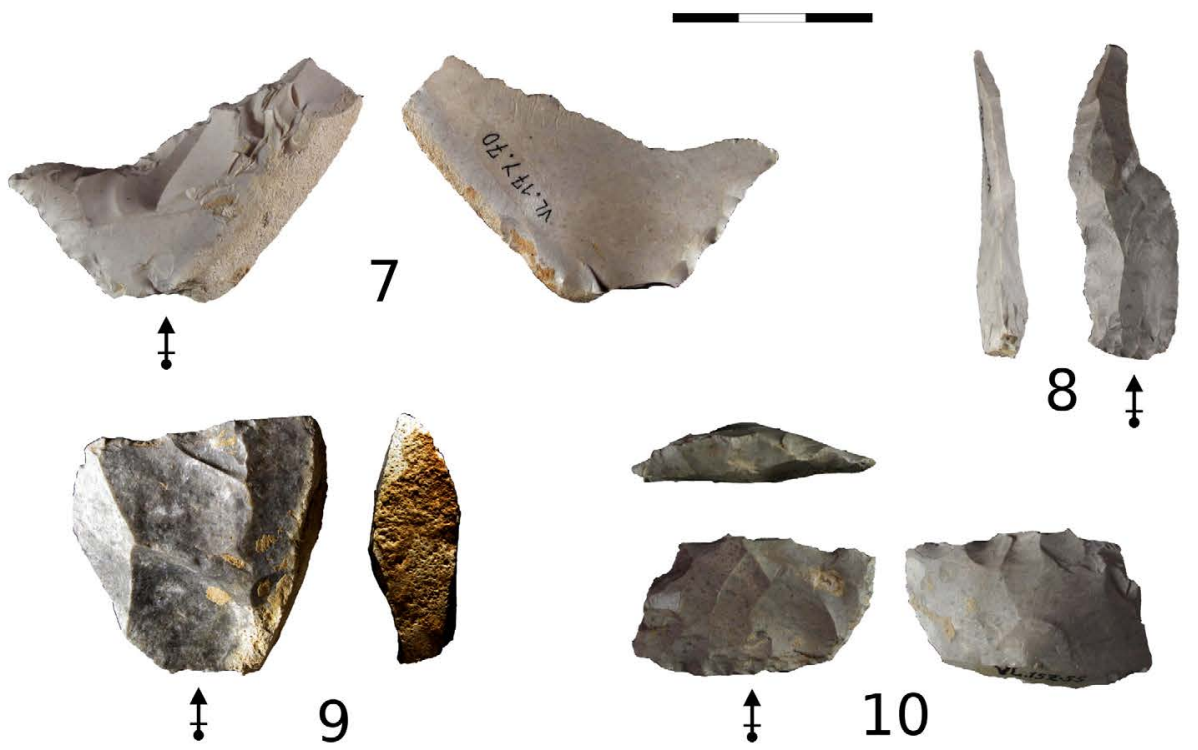

Figure 9. Non-Urgonian flint artefacts. 1-3 dejeté side-scrapers; 4: lateral side-scraper; 5: piece with retouch on ventral surface; 6: denticulate; 7, 10: bifacial denticulates, no. 10 made on a resharpening flake; 8: blade; 9: retouched flake. 
Metric comparisons are partially biased by the fact that very small flakes and fragments $(<10 \mathrm{~mm}$ ) were not originally collected by Barandiaran (Figure 10). Despite this, the analysis of the non-broken flaked products shows that the Urgonian and non-Urgonian flint products are very similar, with quadrangular flakes with tight dimensions around $27 \times 24 \mathrm{~mm}$, whereas bigger and slightly elongated products were obtained from mudstone (Table 3, Figure 10).

Table 3. Metric values (L: Length, W: Width, T: Thickness) of different raw materials (U: Urgonian flint; F: Non-Urgonian flint; M: Mudstone; Q: Quartzite).

\begin{tabular}{lcccccccccccc}
\hline & L-U & L-F & L-M & L-Q & W-U & W-F & W-M & $\mathbf{W}-\mathbf{Q}$ & T-U & T-S & T-M & T-Q \\
\hline N & 16 & 26 & 11 & 5 & 16 & 26 & 11 & 5 & 16 & 26 & 11 & 5 \\
Min & 11 & 11 & 17 & 17 & 14 & 9 & 13 & 14 & 3 & 3 & 4 & 4 \\
Max & 62 & 47 & 102 & 75 & 53 & 51 & 55 & 35 & 17 & 15 & 14 & 10 \\
Mean & 26.5 & 27.34 & 36.54 & 32.8 & 25.5 & 23.46 & 30.54 & 23.2 & 8 & 7.65 & 8.90 & 6.2 \\
\hline Std. error & 3.18 & 2.07 & 7.75 & 10.76 & 2.34 & 2.17 & 4.28 & 3.81 & 1.17 & 0.78 & 1.06 & 1.2 \\
\hline
\end{tabular}
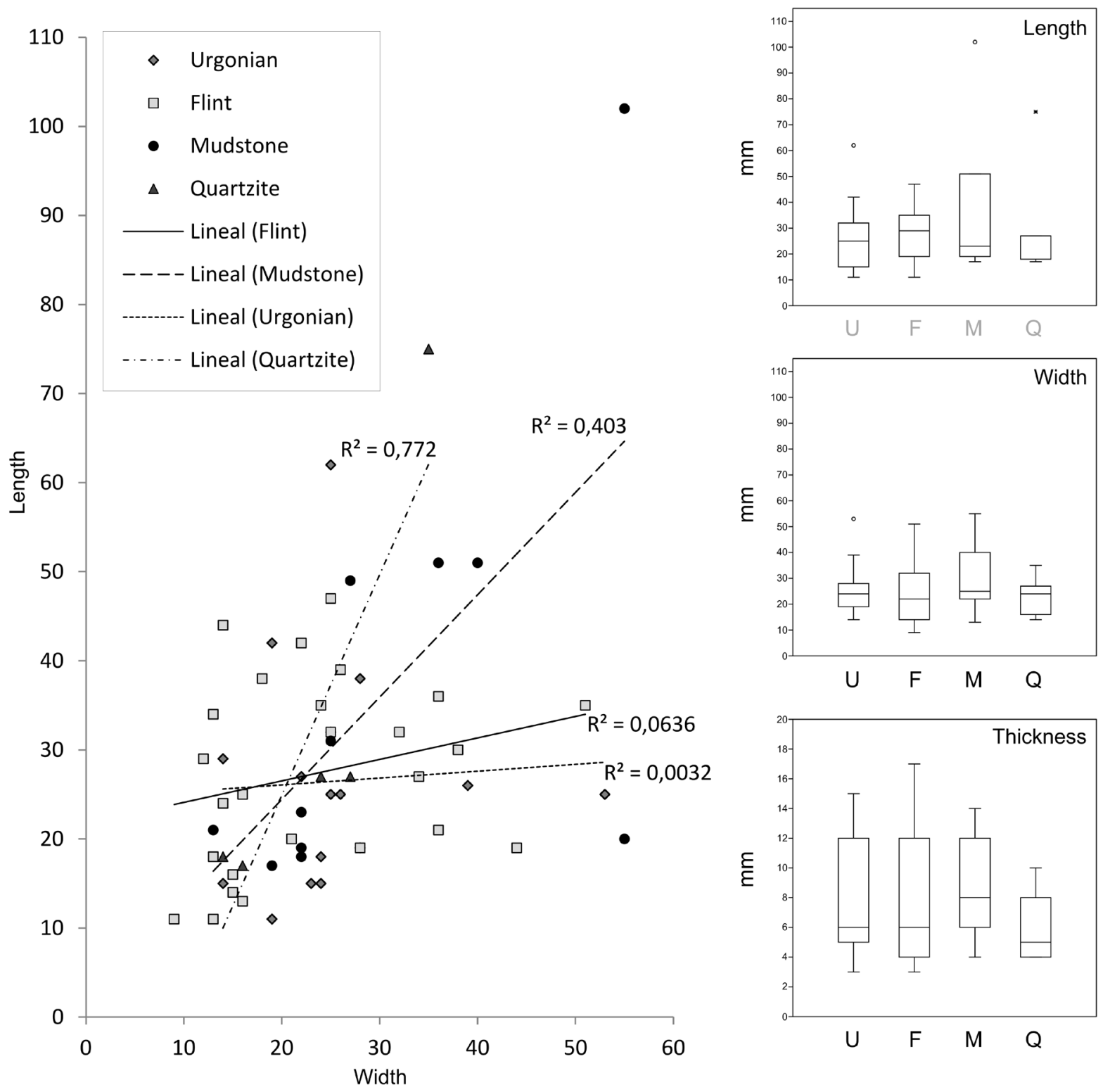

Figure 10. Metric analysis of non-broken flaked products from Ventalaperra's level III. Abbreviations: U Urgonian, F - flint, M - mudstone, Q - quartzite. 
Considering only the non-Urgonian flint assemblage, there are clear metric differences between the retouched products $(\mathrm{N}=10$, mean: $31 \times 34 \times 10 \mathrm{~mm})$ and the non-retouched ones $(\mathrm{N}=16$; mean: $18.5 \times 23 \times 6 \mathrm{~mm})$, some of them corresponding to resharpening flakes.

\section{Discussion}

The specific lithic provisioning strategies developed by the Neanderthal groups at Ventalaperra cave give insights about landscape use, the function of the site and the technical development of these groups. The possible biases introduced by the excavation methodology don't modify substantially the obtained results as the only probable effect would be an increase of the non-flint assemblage. The use of ultra-local raw materials in a rather opportunistic way seems to reflect an adaptation to the low quality of the Urgonian flint which, nevertheless, was used to produce some useful tools like raw flakes or side-scrapers. Local raw materials, basically mudstone, are treated differently. Although mudstone was obtained close to the site, the initial phases of the reduction sequence were probably carried out away from the cave, and only some big cortical flakes, cores that were still useful and raw flakes were transported to the cave. Non-local raw materials, especially flint, show that these Neanderthal groups were moving across an extensive territory that roughly occupied all of the coastal plains from Santander to Bilbao (roughly 80 lineal km). The presence of more distant flint has been noted, but further analyses are needed to demonstrate its origin. During these displacements the group were carrying some already-made, curated tools with them, as well as some raw flakes. Given these characteristic we can differentiate, following S. Kuhn's (1995) criteria, an opportunistic provisioning strategy (Urgonian flint), a provisioning place strategy (mudstone) and a provisioning individual strategy (non-local flint). This technologyprovisioning system seems to fit well with an ephemeral activity area where some intense activities are carried out by a group which is moving, intermediately after, to another locality.

Technological procedures are dominated by complex flaking systems except for most of the Urgonian-flint production. Non-local flint seems to have been produced following a recurrent centripetal Levallois method with some particularities, basically the maintenance of cortical flanks. Moreover, outrepassé flakes with asymmetric sections and cortical backs seem to have been purposefully selected, alongside regular flakes, to configure the mobile toolkit used by the group in their displacements. Local raw materials, in this case mudstone, was exploited following a recurrent centripetal method with features that are linked to the Levallois (the presence of a flat exploitation surface) and Discoid methods (an acute angle of intersection between both surfaces, convex surface also used for production, not only and specifically for platform preparation, and the relative abundance of asymmetrically dihedral platforms). Beside this exploitation, there are big partially-cortical flakes, with asymmetric sections, unidirectional negatives and flat platforms that seem to be closer to the 'orange slice', SSDA or Quina methods.

This technology provisioning system contrasts with the behaviours observed at eastern Cantabrian Late Middle Palaeolithic assemblages. For example, in Axlor's upper levels (F-B VI-III) tool needs were fulfilled with imported tools and blanks which are especially designed to serve as second-generation cores following a ramified Quina system (Rios-Garaizar 2012a; 2005; Rios-Garaizar et al. 2015). In Axlor's lower levels (N-M, VIII-VII) and at Amalda there is a more intense dependence on local raw materials, mudstone and tobaceous mudstone, which, in both cases, is combined with imported flint and in situ flake production from second generation cores following, in this case, a ramified Levallois system (González Urquijo et al. 2006; Rios-Garaizar 2010; 2012a; Rios-Garaizar et al. 2015). Recent observations made on the Late Middle Palaeolithic assemblages from El Cuco rock shelter suggest a similar technological organization (personal observation by the author). The absence of ramified 
productions at Ventalaperra contrasts with these assemblages; also, the use of ultra-local, poor quality, raw materials has not been noted at Axlor or Amalda, except for the production of more massive tools.

When compared to the Early Middle Palaeolithic (EMP) assemblages from Arlanpe cave (Rios-Garaizar 2013; Rios-Garaizar et al. 2015), or the EMP levels at Lezetxiki (Álvarez Alonso \& Arrizabalaga 2012) similar characteristics are noted. For example, at both sites a centripetal recurrent production of mudstone flakes is observed. At Arlanpe the use of the SSDA method to produce asymmetric mudstone flakes has also been attested. Finally, at both sites the import of already-made flint flakes, usually retouched and produced by Levallois methods, has been documented, also suggesting a wide exploitation of the landscape, high mobility and short and intense occupations of the caves (Rios-Garaizar et al. 2015). In the EMP levels, as is the case at Ventalaperra, the presence of ramified productions is occasional. In Axlor level $\mathrm{R}$ and Morin level 18 ramified production has been described (Lazuén \& González-Urquijo 2015) supposedly related to an EMP level, but there is no evidence to sustain a chronology between the Middle and Upper Pleistocene for none of these levels. Axlor level $\mathrm{R}$ is attributed to late Middle Pleistocene because its position below level $\mathrm{N}$, which has not been dated. Same can be said for Morin 18, up to now this level has not been directly dated, and the chronological estimation for Morin 17 situates it at Würm II (Baena et al. 2004). Moreover, given the actual description of both assemblages (high percentages of flint use, ramified productions), they are very different from what has been observed in the region's key EMP sequences (Lezetxiki VI and VII, Arlanpe SQ1-3, Castillo 24-26) (ÁlvarezAlonso 2014; Rios-Garaizar et al. 2015), and they fit perfectly with the variability of LMP industries, so there is no chronological nor technological evidence to interpret these assemblages as being EMP.

EMP industries similar to the Eastern Cantabrian sites have been defined at Late Middle Pleistocene sites located at neighbouring regions as the Duero Bassin (Sánchez Yustos \& Díez Martín 2015), SW France (Turq et al. 2010) or central Cantabrian Region (ÁlvarezAlonso 2014). These assemblages are characterized by the development of non-specialized complex systems of flake production which is the main characteristic of western European EMP (Baena et al. 2014; Moncel et al. 2011; Picin et al. 2013; Turq et al. 2010). Other aspects as the relevance in EMP assemblages of ramified strategies have not been thoroughly explored, but as we have shown at least for the eastern Cantabrian Region there is a clear difference regarding this technological behaviour between EMP and LMP. Same can be said for raw-material provisioning. It has been noted that Neanderthal populations relied mostly on local raw materials (Turq et al. 2013). This is also the case in central and western Cantabrian Region, where lithic provisioning systems relies mostly on local raw materials (García Garriga et al. 2012, Sarabia 1995). But, looking at a closer scale, we also observe a clear difference between EMP and LMP provisioning strategies in the eastern Cantabrian Region (Arrizabalaga 2011; Rios-Garaizar 2012a).

Therefore, it seems that the reliance on local raw materials for in situ productions, the lesser importance of ramified productions and the combined use of Levallois-like technologies with other production strategies, are characteristic of this region's EMP. This interpretation fits well with the characteristics observed in Ventalaperra's level III. Additional evidence for such an attribution can be found in the Abrigo Rojo rock shelter, a nearby site most probably dating back to the end of the Middle Pleistocene (González-Morales personal communication), where a similar industry with plan-convex centripetal mudstone cores, intensive use of Urgonian flint, some imported non-local flint flakes and tools and almost no ramified productions has been identified (personal observation by the author). Also the subsistence practices that can be inferred from the faunal assemblage corresponding to level 
4, published by P. Castaños (2005) suggest a high dependence on local resources, especially from rocky-environment ungulates, which, given the location of the cave, were surely very abundant in the surroundings. A similar subsistence strategy has been documented at the Late Middle Pleistocene site of Arlanpe (Arceredillo-Alonso et al. 2013; Rios-Garaizar et al. 2015) and in the Upper Pleistocene site of Amalda (Altuna 1990; Rios-Garaizar 2012b). In Lezetxiki VI and VII's Middle Pleistocene levels, and in the Upper Pleistocene sites of Axlor and Arrillor, the faunal assemblages show clear selective patterns that are less reliant on local fauna (Rios-Garaizar \& García-Moreno 2015).

Finally, the stratigraphic position of level III (level 4 in the new excavations), under a thick flowstone above which Upper Pleistocene industries are placed, can also provide additional evidence when estimating the chronology of this deposit. Few sites in the Cantabrian record present Middle Palaeolithic occupations below thick flowstones, among them Lezetxiki II, Arlanpe, Covalejos and Castillo, and at all of these the dates obtained from these flowstones are always older than 89,000 BP (Castaños et al. 2011; Rink et al. 1997; Rios-Garaizar et al. 2015; Sanguino \& Montes Barquín 2005). Recent work on karst evolution in the eastern Cantabrian Region suggest that major flowstone formation episodes occurred during MIS9, MIS5-6 and the Holocene, being Urtiaga II the only cave with a flowstone dated to MIS4-2 (Aranburu et al. 2015).

Taking into account these data we can quite confidently interpret Ventalaperra level III's (4) archaeological assemblage as representing short Early Middle Palaeolithic occupations that took place roughly at the end of the Middle Pleistocene. Thus, to the best of our knowledge, there is no evidence to state that this level can be attributed to the Late Middle Palaeolithic, let alone the Aurignacian.

\section{Conclusions}

Research on human presence during the Late Middle Pleistocene in the eastern Cantabrian Region has significantly advanced in the past several years, thanks to the publication of new sequences such as Arlanpe, and to the review of already-known sites such as Lezetxiki. This specific period is greatly relevant to our understanding of the complex cultural changes that took place between the Lower and Middle Palaeolithic (Monnier 2006; Santonja et al. 2014), and is also important for our understanding of Neanderthal cultural evolution. The review of Ventalaperra level III's lithic assemblage has provided elements to suggest an Early Middle Palaeolithic attribution and a Late Middle Pleistocene chronology for these occupations. The interpretation of the lithic provisioning system at Ventalaperra reinforces previous interpretations derived from the study of Arlanpe and Lezetxiki's material. Early Middle Palaeolithic Neanderthal groups used the landscape in a similar way: high mobility and wide territories $(>60 \mathrm{~km})$ are inferred from raw material provenance studies and the way in which these non-local raw materials were introduced at the sites. The occupations at these sites are short and rather intense, and the technological needs, which varied from one site to site, were fulfilled using imported tools and local raw materials, and subsistence is based mainly on local resources. This reveals a behavioural pattern for Early Middle Palaeolithic populations in the eastern Cantabrian Region characterized by an extensive use of landscape, high mobility, short occupations and high dependence on local resources to assure subsistence and technological provisioning, which is different to the regional Late Middle Palaeolithic behavioural pattern where more complex provisioning strategies can be observed. 


\section{Acknowledgements}

Lithic collections from Barandiaran and Aranzadi excavations are curated at the Arkeologi Museoa of Bilbao (Basque Country) whose curators and director were very helpful. The original manuscript was enriched with the comments by Dr. Diego Garate. Also Professor Manuel González Morales give us some valuable information about the Abrigo Rojo site. Finally, Dr. Pía Spry-Marqués corrected the English version of the text also giving some useful comments on it. Also, I wish to thank the comments provided by the two anonymous reviewers.

\section{References}

Alcalde del Río, H., Breuil, H., \& Sierra, L. 1912, Les cavernes de la région cantabrique (Espagne). A. Chêne, Monaco, 265 p. (in French) ("The caves of Cantabrian Region (Spain)")

Altuna, J. 1990, Caza y alimentación procedente de los Macromamíferos durante el Paleolítico de Amalda. In: La Cueva de Amalda (Zestoa, País Vasco); Ocupaciones Paleolíticas y Postpaleolíticas, (Altuna, J., Baldeón, A., \& Mariezkurrena, K., Eds.), Sociedad de Estudios Vascos, Donostia-San Sebastián: p. 149-192. (in Spanish) ("Hunting and macromammal based subsistence in the Paleolithic at Amalda")

Álvarez Alonso, D., \& Arrizabalaga, A. 2012, La secuencia estratigráfica inferior de la cueva de Lezetxiki (Arrasate, País Vasco). Una reflexión necesaria. Zephyrus, 69: 15-29. (in Spanish) ("Lower stratigraphical sequence of Lezetxiki cave (Arrasate, Basque Country). A necessary reflection”) URL: http://revistas.usal.es/index.php/05147336/article/view/9028

Álvarez-Alonso, D. 2014, First Neanderthal settlements in northern Iberia: The Acheulean and the emergence of Mousterian technology in the Cantabrian region. Quaternary International, 326-327: 288-306. doi:10.1016/j.quaint.2012.12.023

Aranburu, A., Arriolabengoa, M., Iriarte, E., Giralt, S., Yusta, I., Martínez-Pillado, V., del Val, M., Moreno, J., \& Jiménez-Sánchez, M. 2015, Karst landscape evolution in the littoral area of the Bay of Biscay (north Iberian Peninsula). Quaternary International, 364: 217-230. doi:10.1016/j.quaint.2014.09.025

Arceredillo-Alonso, D., Gómez-Olivencia, A. \& San Pedro-Calleja, Z. 2013, La fauna de macromamíferos de los niveles pleistocenos de la Cueva de Arlanpe. In: La cueva de Arlanpe (Lemoa): Ocupaciones humanas desde el Paleolítico Medio Antiguo hasta la Prehistoria Reciente. Kobie Serie BAI 3, (Rios-Garaizar, J., Garate Maidagan, D. \&Gómez-Olivencia, A., Eds.), Diputación Foral de Bizkaia, Bilbao: p. 123-160 (in Spanish) ("Macromammal faunal remains from the Pleistocene levels of Arlanpe cave (Lemoa, Biscay)”)

Arrizabalaga, A. 1995, La industria lítica del Paleolítico Superior Inicial en el Oriente Cantábrico. PhD Thesis at the Departamento de Geografía, Prehistoria y Arqueología, Universidad del País Vasco, Vitoria-Gasteiz, 1050 p. (in Spanish) ("Eastern Cantabrian Region Initial Upper Paleolitic lithic industry")

Arrizabalaga, A. 2005, Las primeras ocupaciones humanas en el Pirineo Occidental y Montes Vascos: un estado de la cuestión en 2005. Munibe (Antropologia-Arkeologia).

Homenaje al Prof. Jesús Altuna, 57: 53-70. (in Spanish) ("First human settlements in the Western Pyrenees and Basque Mountains. The state of question in 2005”) 
Arrizabalaga, Á. 2010, La dialéctica sílex/otras materias primas en la evolución de los recursos líticos durante el Paleolítico vasco. Algunas consideraciones técnicas, económicas y culturales, In: Minerales Y Rocas En Las Sociedades de La Prehistoria, (Domínguez-Bella, S., Ramos-Muñoz, J., Gutiérrez-López, J.M. \& Pérez Rodríguez, M., Eds.), Grupo Investigacion Hum-440, Cadiz: p. 83-90. (in Spanish) ("Flint/Other materials dialectics for the evolution of lithic resources in the Basque Country's Paleolithic. Some technical, economic and cultural considerations”)

Baena, J., Cabrera, V. \& Carrión, V. 2004, Las sociedades neandertales durante el final del Paleolítico Medio. In: Las Sociedades del Paleolítico en el Cantábrico, Kobie Anejo 8, (Fano, M. Ed.), Bilbao, Diputación Foral de Bizkaia, p. 91-140. (in Spanish)

("Neanderthal societies at the end of Middle Paleolithic")

Baena, J., Moncel, M.-H., Cuartero, F., Chacón Navarro, M.G. \& Rubio, D. 2014 (in press), Late Middle Pleistocene genesis of Neanderthal technology in Western Europe: The case of Payre site (south-east France). Quaternary International, (in press). doi:10.1016/j.quaint.2014.08.031

Baldeón, A. 1987, El Paleolítico Medio en el País Vasco. PhD Thesis at the Universidad de Deusto, Bilbao, 1967 p. (in Spanish) (Middle Paleolithic in the Basque Country”)

Baldeón, A. 1990, El Paleolítico Inferior y Medio en el País Vasco. Una aproximación en 1990. Munibe (Antropologia-Arkeologia), 42: 11-22. (in Spanish) ("Lower and Middle Paleolithic in the Basque Country. An overview from 1990”)

Barandiarán, J.M. 1958, Excavaciones en Carranza, Bortal, Venta de Laperra, Polvorín. Vizcaya, 10: 49-52. (in Spanish) (Excavations at Carranza, Bortal, Venta de Laperra, Polvorín”)

Barandiarán, J.M. 1978, Exploración de las cuevas de Polvorín y Venta de Laperra. In: Homenaje a Julio Caro Baroja, (Carreira, A. Ed.), Centro de Investigaciones Sociológicas, Madrid: p. 109-129. (in Spanish) (Explorations at Polvorín and Venta de Laperra Caves”)

Bourguignon, L., Faivre, J.-P. \& Turq, A. 2004, Ramification des chaînes opératoires: une spécificité du Moustérien?, Paléo, 16: 37-48. (in French) (The ramification of reduction sequences: a Mousterian specificity?”)

Castaños, P. 2005, Revisión actualizada de las faunas de macromamíferos del Würm antiguo en la Región Cantábrica. In: Actas de La Reunión Científica: Neandertales Cantábricos. Estado de La Cuestión, (Montes Barquín, R. \& Lasheras Corruchaga, J.A. Eds.), Ministerio de Cultura, Madrid: p. 201-207. (in Spanish) ("Updated revision of Cantabrian Region Early Wúrm macrommamal assemblages”)

Castaños, P., Murelaga, X., Arrizabalaga, A. \& Iriarte, M.-J. 2011, First evidence of Macaca sylvanus (Primates, Cercopithecidae) from the Late Pleistocene of Lezetxiki II cave (Basque Country, Spain). Journal of Human Evolution, 60: 816-820. doi:10.1016/j.jhevol.2011.01.011

Garcia Garriga, J., Martínez Molina, K. \& Baena Preysler, J. 2012, Neanderthal Survival in the North of the Iberian Peninsula? Reflections from a Catalan and Cantabrian Perspective. Journal of World Prehistory, 25: 81-121. doi:10.1007/s10963-012-9057-y

Geneste, J.-M. 1988, Les industries de la grotte Vaufrey: technologie du débitage, économie et circulation de la matière première lithique. In: La Grotte Vaufrey À Cenac et Saint Julien (Dordogne): Paléoenvironnements, Chronologie et Activités Humaines. 
Mémoires de La Société Préhistorique Française 19, (Rigaud, J.-P. Ed.), Societé Préhistorique Française, Paris: p. 441-519. (in French) ("Vaufrey cave's industries: knapping technology, economy and raw material circulation”)

González Sáinz, C. \& San Miguel Llamosas, C. 2001, Las Cuevas del Desfiladero: Arte Rupestre Paleolítico en el Valle del Río Carranza (Cantabria-Vizcaya). Universidad de Cantabria, Santander, 228 p. (in Spanish) ("The caves of the gorge: paleolithic rock-art in the valley of the river Carranza (Cantabria-Biscay)")

González Urquijo, J.E., Ibáñez Estévez, J.J., Ríos Garaizar, J. \& Bourguignon, L. 2006, Aportes de las nuevas excavaciones en Axlor sobre el final del Paleolítico Medio. In: Ante El Centenario de La Cueva de El Castillo: El Ocaso de Los Neandertales, (Cabrera Valdés, V., Bernaldo de Quirós \& F., Maíllo, J.M. Eds.). Universidad Nacional de Educación a Distancia, Santander: p. 269-291. (in Spanish) (“Contributions of new excavations at Axlor's Late Middle Palaeolithic”)

Higham, T., Douka, K., Wood, R., Ramsey, C.B., Brock, F., Basell, L., Camps, M., Arrizabalaga, A., Baena, J., Barroso-Ruiz, C., Bergman, C., Boitard, C., Boscato, P., Caparros, M., Conard, N.J., Draily, C., Froment, A., Galvan, B., Gambassini, P., Garcia-Moreno, A., Grimaldi, S., Haesaerts, P., Holt, B., Iriarte-Chiapusso, M.-J., Jelinek, A., Jorda Pardo, J.F., Maillo-Fernandez, J.-M., Marom, A., Maroto, J., Menendez, M., Metz, L., Morin, E., Moroni, A., Negrino, F., Panagopoulou, E., Peresani, M., Pirson, S., de la Rasilla, M., Riel-Salvatore, J., Ronchitelli, A., Santamaria, D., Semal, P., Slimak, L., Soler, J., Soler, N., Villaluenga, A., Pinhasi, R. \& Jacobi, R. 2014, The timing and spatiotemporal patterning of Neanderthal disappearance. Nature, 512: 306-309. doi:10.1038/nature13621

Kuhn, S.L. 1995, Mousterian lithic technology: an ecological perspective. Princeton University Press, Princeton, 209 p.

Lazuén, T. \& González-Urquijo, J. 2015, Recycling in the Early Middle Paleolithic: The role of resharpening flakes assessed through techno-functional analysis. Quaternary International, 361: 229-237. doi:10.1016/j.quaint.2014.04.008

Moncel, M.-H., Moigne, A.-M., Sam, Y. \& Combier, J. 2011, The Emergence of Neanderthal Technical Behavior: New Evidence from Orgnac 3 (Level 1, MIS 8), Southeastern France. Current Anthropology, 52: 37-75. doi:10.1086/658179

Monnier, G.F. 2006, The Lower/Middle Paleolithic Periodization in Wenstern Europe. An Evaluation. Current Anthropology, 47: 709-744. doi:10.1086/506280

Montes. R. 2003, El primer poblamiento de la Región Cantábrica. El Paleolítico Inferior Cantábrico. Ministerio de Cultura, Madrid, 260 p. (in Spanish) ("The first peopling of the Cantabrian Region. The cantabrian Lower Paleolithic”)

Muñoz Fernández, E. 2005, El Musteriense en el centro de la Región Cantábrica. In: Actas de La Reunión Científica: Neandertales Cantábricos. Estado de La Cuestión, (Montes Barquín, R. \& Lasheras Corruchaga, J.A., Eds.), Ministerio de Cultura, Madrid: p. 75100. (in Spanish) ("The Mousterian in the center of the Cantabrian Region").

Murelaga, X., Saez de la Fuente, X., Castaños, P., Ruiz Idarraga, R., d'Errico, F. \& Zubeldia, H. 2007, Estudio de los micromamíferos del Pleistoceno superior de Ventalaperra (Karrantza, Bizkaia). Geogaceta, 42: 95-98. (in Spanish) ("Study of the micromammals from the Upper Pleistocene of Ventalaperra (Karrantza, Bizkaia)”) 
Picin, A., Peresani, M., Falguères, C., Gruppioni, G. \& Bahain, J.-J. 2013, San Bernardino Cave (Italy) and the Appearance of Levallois Technology in Europe: Results of a Radiometric and Technological Reassessment. PLoS ONE, 8(10): e76182. doi:10.1371/journal.pone.0076182

Rink, W.J., Schwarcz, H.P., Lee, H.K., Cabrera Valdés, V., Bernaldo de Quirós, F. \& Hoyos, M. 1997, ESR dating of Mousterian levels at El Castillo Cave, Cantabria, Spain. Journal of Archaeological Science, 24: 593-600. doi:10.1006/jasc.1996.0143

Rios-Garaizar, J. 2005, Características de la producción lítica al final del Paleolítico Medio en el País Vasco. El caso del nivel B de Axlor (Dima, Bizkaia). In: Actas de La Reunión Científica: Neandertales Cantábricos. Estado de La Cuestión, (Montes Barquín, R. \& Lasheras Corruchaga, J.A. Eds.), Ministerio de Cultura, Madrid: p. 333-348. (in Spanish) ("Basque Country's Late Middle Paleolithic lithic production characteristics. The case of Axlor level B (Dima, Biscay)”).

Rios-Garaizar, J. 2010, Organización económica de las sociedades Neandertales: el caso del nivel VII de Amalda (Zestoa, Gipuzkoa). Zephyrus, 65: 15-37. (in Spanish) (“Economic organization among Neanderthals: Amalda (Basque Country, Spain) level VII Mousterian”) URL: http://hdl.handle.net/10366/100641

Rios-Garaizar, J. 2012a, Industria lítica y sociedad en la Transición del Paleolítico Medio al Superior en torno al Golfo de Bizkaia. PUbliCan - Ediciones de la Universidad de Cantabria, Santander, 564 p. (in Spanish) ("Lithic industry and society from the Middle to Upper Palaeolithic transition around the Bay of Biscay”)

Rios-Garaizar, J. 2012b, Técnicas de caza en el Paleolítico Medio del País Vasco. Isturitz. Cuadernos de Sección. Prehistoria-Arqueologia, 12: 7-37. (in Spanish) (“Hunting Techniques in the Middle Palaeolithic in Basque Country”) URL: http://www.euskoikaskuntza.org/es/publicaciones/colecciones/cuadernos/articulo.php?o=21898

Rios-Garaizar, J. 2013, Industria lítica de los niveles del Paleolítico Medio Antiguo y Paleolítico Superior de Arlanpe (Lemoa, Bizkaia). In: La cueva de Arlanpe (Lemoa): Ocupaciones humanas desde el Paleolítico Medio Antiguo hasta la Prehistoria Reciente. Kobie Serie BAI 3, (Rios-Garaizar, J., Garate Maidagan, D. \& GómezOlivencia, A., Eds.), Diputación Foral de Bizkaia, Bilbao: p. 177-253. (in Spanish) ("Early Middle Paleolithic and Upper Paleolithic lithic assemblages from Arlanpe cave (Lemoa, Biscay)”)

Rios-Garaizar, J., Garate Maidagan, D., Iriarte Avilés, E., Cearreta Bilbao, A. \& Iriarte Chiapusso, M.J. 2010, Los yacimientos de Mendieta I y II (Sopelana, Bizkaia): dos ocupaciones al aire libre del Paleolítico Inferior y Medio. Kobie (Paleoantropología), 29: 7-18. (in Spanish) ("Mendieta I and II (Sopelana, Bizkaia): two open air sites of Lower and Middle Paleolithic") URL: http://www.bizkaia.eus/fitxategiak/04/ondarea/Kobie/PDF/2/Kobie29_01.pdf

Rios-Garaizar, J., de la Peña, P. \& San Emeterio, A. 2011, Estudio de las industrias líticas y óseas de la cueva de Aitzbitarte III (Zona de la entrada). In: Ocupaciones Humanas En La Cueva de Aitzbitarte III (Renteria, País Vasco) Sector Entrada: 33.000-18.000 BP, (Altuna, J., Mariezkurrena, K. \& Rios-Garaizar, J. Eds.), Eusko Jaurlaritzaren Argitalpen Zerbitzu Nagusia, Vitoria-Gasteiz: p. 81-351. (in Spanish) (“Analysis of the lithic and bone industry of the Aitzbitarte III cave (Entrance to the cave)”) 
Rios-Garaizar, J., Eixea, A. \& Villaverde, V. 2015, Ramification of lithic production and the search of small tools in Iberian Peninsula Middle Paleolithic. Quaternary International, 361: 188-199. doi:10.1016/j.quaint.2014.07.025

Rios-Garaizar, J., Garate Maidagan, D., Gómez-Olivencia, A., Iriarte, E., Arceredillo-Alonso, D., Iriarte-Chiapusso, M.J., Garcia-Ibaibarriaga, N., García-Moreno, A., GutierrezZugasti, I., Torres, T., Aranburu, A., Arriolabengoa, M., Bailón, S., Murelaga, X., Ordiales, A., Ortiz, J.E., Rofes, J. \& San Pedro, Z. 2015, Short-term Neandertal occupations in the late Middle Pleistocene of Arlanpe (Lemoa, northern Iberian Peninsula). Comptes Rendus Palevol, 14: 233-244. doi:10.1016/j.crpv.2014.11.006

Rios-Garaizar, J. \& García-Moreno, A. 2015, Middle Paleolithic Mobility Patterns and Settlement System Variability in the Eastern Cantabrian Region (Iberian Peninsula): A GIS-Based Resource Patching Model. In: Settlement Dynamics of the Middle Paleolithic and Middle Stone Age Vol. 4 (Conard, N.J. \& Delagnes, A. Eds.), Kerns Verlag, Tübingen: p. 329-360

Rios-Garaizar, J. 2004, La Transición del Paleolítico Medio al Superior en torno al Golfo de Bizkaia. Una aproximación desde el análisis de la producción y de la gestión del utillaje lítico de los niveles Musterienses (A-D) de Axlor (Dima, Bizkaia) y de la ocupación Auriñaciense al aire libre de Barbas III (Creysse, Dordogne). Master of Arts thesis at the Departamento de Ciencias Históricas. Universidad de Cantabria, Santander, 272 p. (in Spanish) ("The Transition from Middle to Upper Paleolithic around the Bay of Biscay. An approach from the analysis of the production and management of the stone tools of the Mousterian levels (A-D) of Axlor (Dima, Bizkaia) and the Aurignacian open air occupation at Barbas III (Creysse, Dordogne)”)

Rissetto, J.D. 2005, Using Lithic Procurement Strategies to Define Magdalenian HunterGatherer Mobility Patterns in the Asón Valley of Eastern Cantabria, Spain. In: $O$ Paleolítico: Actas Do IV Congresso de Arqueologia Peninsular (Faro, 14 a 19 de Setembro de 2004), (Bicho, N. \& Corchón Rodríguez, S. Eds.), Centro de Estudos de Patrimonio, Departamento de Historia, Arqueologia e Patrimonio, Universidade do Algarve, Faro: p. 481-492.

Rissetto, J.D. 2008, Siliceous raw materials from Eastern Cantabria, Spain. FlintSource.NET. Retrieved 10 October 2015. URL: http://www.flintsource.net/flint/infE_cantabria.html

Ruiz Cobo, J. \& Smith, P. 2003, La Cueva de Cofresnedo en el Valle de Matienzo. Actuaciones Arqueológicas 1996 - 2001. Consejería de Cultura, Turismo y Deporte. Gobierno de Cantabria, Santander, 198 p. (in Spanish) ("Cofresnedo cave in the Matienzo Valley. Archaeological works 1996-2001”)

Ruiz Idarraga, R. \& d'Errico, F. 2002, Cueva de Ventalaperra (Valle de Carranza). I Campaña. Arkeoikuska: Investigación arqueológica, 2001: 100-102. (in Spanish) ("Ventalaperra cave (Carranza Valley). I Campaing”)

Ruiz Idarraga, R. \& d'Errico, F. 2003, Cueva de Ventalaperra (Valle de Carranza). II Campaña. Arkeoikuska: Investigación arqueológica, 2002: 87-88. (in Spanish) ("Ventalaperra cave (Carranza Valley). II Campaing")

Ruiz Idarraga, R. \& d'Errico, F. 2004, Cueva de Ventalaperra (Valle de Carranza). III Campaña. Arkeoikuska: Investigación arqueológica, 2003: 93-94. (in Spanish) ("Ventalaperra cave (Carranza Valley). III Campaing”) 
Ruiz Idarraga, R. \& d'Errico, F. 2005, Cueva de Ventalaperra (Valle de Carranza). VI Campaña. Arkeoikuska: Investigación arqueológica, 2004: 96-97. (in Spanish) ("Ventalaperra cave (Carranza Valley). IV Campaing”)

Ruiz Idarraga, R. \& d'Errico, F. 2007, Cueva de El Polvorín (Valle de Carranza). Arkeoikuska: Investigación arqueológica, 2006: 136-137. (in Spanish) ("Polvorín cave (Carranza Valley)")

Sánchez Yustos, P. \& Diez Martín, F., 2015. Dancing to the rhythms of the Pleistocene? Early Middle Paleolithic population dynamics in NW Iberia (Duero Basin and Cantabrian Region). Quaternary Science Reviews, 121: 75-88. doi:10.1016/j.quascirev.2015.05.005

Sanguino, J. \& Montes Barquín, R. 2005, Nuevos datos para el conocimiento del Paleolítico Medio en el centro de la Región Cantábrica: la cueva de Covalejos (Pielagos, Cantabria). In: Actas de La Reunión Científica: Neandertales Cantábricos. Estado de La Cuestión, (Montes Barquín, R. \& Lasheras Corruchaga, J.A. Eds.), Ministerio de Cultura, Madrid: p. 489-504. (in Spanish) ("New data about Middle Palaeolithic in the central part of the Cantabrian Region: Covalejos cave (Pielagos, Cantabria)”)

Santonja, M., Pérez-González, A., Domínguez-Rodrigo, M., Panera, J., Rubio-Jara, S., Sesé, C., Soto, E., Arnold, L.J., Duval, M., Demuro, M., Ortiz, J.E., de Torres, T., Mercier, N., Barba, R. \& Yravedra, J. 2014, The Middle Paleolithic site of Cuesta de la Bajada (Teruel, Spain): a perspective on the Acheulean and Middle Paleolithic technocomplexes in Europe. Journal of Archaeological Science, 49: 556-571. doi:10.1016/j.jas.2014.06.003

Sarabia, P. 1995, Las estrategias de aprovisionamiento de materias primas líticas en la Transición del Paleolítico Medio- Superior en Cantabria. In: Actas Del XXII Conrgreso Nacional de Arqueología (1993). Xunta de Galicia, Consellería de Cultura, Comunicación Social e Turismo, Vigo: p. 357-365. (in Spanish) ("Lithic raw-material provisioning strategies during the Middle to Upper Paleolithic transition in Cantabria”)

Straus, L.G. \& González Morales, M.R. 2003, El Mirón Cave and the 14C Chronology of Cantabrian Spain. Radiocarbon, 45: 41-58.

URL: https://journals.uair.arizona.edu/index.php/radiocarbon/article/view/4158

Tarriño, A., Elorrieta, I. \& García-Rojas, M. 2015, Flint as raw material in prehistoric times: Cantabrian Mountain and Western Pyrenees data. Quaternary International, 364: 94108. doi:10.1016/j.quaint.2014.10.061

Tarriño, A. 2006, El sílex en la cuenca Vasco-Cantábrica y Pirineo Navarro. Ministerio de Cultura, Madrid, 264 p. (in Spanish) ("Flint in the Basque-Cantabrian bassin and Navarre Pyrenees”)

Turq, A., Brenet, M., Colonge, D., Jarry, M., Lelouvier, L.-A., O’Farrell, M. \& Jaubert, J. 2010, The first human occupations in southwestern France: A revised summary twenty years after the Abbeville/Saint Riquier colloquium. Quaternary International, 223-224: 383-398. doi:10.1016/j.quaint.2010.03.012

Turq, A., Roebroeks, W., Bourguignon, L. \& Faivre, J.-P. 2013, The fragmented character of Middle Palaeolithic stone tool technology. Journal of Human Evolution, 65: 641-655. doi:10.1016/j.jhevol.2013.07.014 